\title{
The genus Matricaria L. (Asteraceae) in Turkey
}

\section{Huseyin Inceer}

Karadeniz Technical University, Faculty of Science, Department of Biology, 61080 Trabzon, Turkey, e-mail: inceer@ktu.edu.tr, ORCID: http://orcid.org/0000-0003-1344-8747

\begin{abstract}
In this study, a report on the genus Matricaria in Turkey is provided based on floristic studies. Previously recorded taxa are compared with new ones from our collections. Four taxa of Matricaria in Turkish flora are recognized: M. aurea, M. chamomilla var. chamomilla, M. chamomilla var. recutita and M. matricarioides. On the other hand, M. chamomilla var. coronata is an erroneous record for the flora of Turkey. Diagnostic morphological characters together with data on phenology, habitat and distribution as well as dichotomous keys for Matricaria taxa are presented. Proportions of various phytogeographical elements of Matricaria taxa in Turkey are provided.
\end{abstract}

Key words: Matricaria, morphology, phytogeography, taxonomy, Turkish flora

\section{Introduction}

Matricaria L. is a small genus of the tribe Anthemideae with 6 species, mostly distributed in Europe, northern Africa, Macaronesia, western, south-western and central Asia, and western North America (Oberprieler et al. 2007). The wide range of geographical distribution and diversity of habitats, such as disturbed meadows, vacant lots, areas along roads and railroads, waste and dry areas, in which Matricaria occurs may result in different adaptations to diverse environments (Inceer 2011).

Matricaria is classified in subtribe Matricariinae of the Anthemideae (Bremer \& Humphries 1993), together with several other similar genera, for instance, Tripleurospermum Sch.Bip., which is distinguished by its adaxially strongly 3-ribbed fruits (Bremer et al. 1996). However, these genera have been confused with one another, both taxonomically and nomenclaturally (Applequist 2002). Additionally, Rauschert (1974) and Kay (1976) misapplied the name Matricaria to refer, exclusively, to the species of Tripleurospermum (Bremer \& Humphries 1993).

The systematic position of Matricaria taxa has been determined differently by a number of authors. In particular, the opinions of various authors on $M$. chamomilla $\mathrm{L}$. and $M$. recutita $\mathrm{L}$. are very different.
Some authors recognized a single species as $M$. recutita $(=$ M. chamomilla) or M. chamomilla (Bremer \& Humphries 1993; Greuter \& Raab-Straube 2008), while some authors preferred M. chamomilla with two varieties as var. recutita (L.) Fiori, var. coronata J. Gay ex Boiss or var. pappulosa Margot \& Reut. (Grierson 1974, 1975; Applequist 2002).

The genus Matricaria was revised for the Flora of Turkey and the East Aegean Islands (Grierson 1975), with five taxa and three species recognized: $M$. aurea (Loefl.) Sch. Bip., M. chamomilla var. chamomilla, $M$. chamomilla var. recutita M. chamomilla var. pappulosa and M. macrotis Rech. f. Later, M. matricarioides (Less.) Porter ex Britton was added to the Flora of Turkey (Davis et al. 1988). However, Oberprieler \& Vogt (2006) transferred M. macrotis to Anthemis L. Recently, this classification was followed by Inceer (2012), and Matricaria chamomilla var. pappulosa as M. chamomilla var. coronata was noted as a doubtful record for the Turkish flora by the same author. The total number of Matricaria taxa as well as phytogeographical elements of the taxa in Turkey is still unclear. The aim of this study is to expand taxonomic knowledge of Matricaria taxa in Turkey, including the main diagnostic morphological characters, habitat, distribution patterns and keys for the identification of the taxa. 


\section{Materials and methods}

The present investigation was built upon extensive field studies and inspection of herbarium collections at ANK, B, E, EGE, EDTU, G, GAZI and HUB. Plant materials were collected from many parts of Turkey. Vouchers are deposited in the herbarium at Karadeniz Technical University, Department of Biology (KTUB).

The nomenclature adopted by Grierson (1975), Vogt \& Oberprieler (2006) and Inceer (2012) are herein followed. Terminology of the main phytochoria (East Mediterranean, Central Anatolian, Euxine, ArmenoIranian) is based on the classical work of Takhtajan (1986). Life form of the taxa is identified following the system of Raunkiaer (1934).

\section{Results and taxonomical discussion}

Based on herbarium and field studies, four taxa and three species of Matricaria in Turkish flora are recognized: M. aurea, M. chamomilla var. chamomilla, M. chamomilla var. recutita and M. matricarioides. On the other hand, M. chamomilla var. coronata is an erroneous record for the flora of Turkey. Therefore, this erroneous record was excluded from Turkish Matricaria in this paper. A revised identification key for Matricaria in Turkey is provided below:
Key to the species of Matricaria in Turkey

1. Capitula radiate M. chamomilla

1 * Capitula discoid 2

2. Achenes copiously mucilaginous; corona absent .... M. aurea

2* Achenes non-mucilaginous; corona present M. matricarioides

1. Matricaria aurea (Loefl.) Sch. Bip. Bonplandia 8: 369 (1860), (Fig. 1a).

Morphology: The plant is annual. Roots are slender, weak with numerous branches. Stems are $5-45 \mathrm{~cm}$ tall, glabrous or, sometimes, sparsely pubescent below inflorescence. Leaves are 2-3-pinnatisect and linear-oblanceolate. Capitula are solitary or 2-3 at branch ends, glabrous or sparcely pubescent peduncles. The receptacle is ovoid. Involucral bracts are elliptical, obtuse, green with brown and whitish membranous margins. All florets are tubular, numerous, yellow with 4 lobes, ca. $1.25 \mathrm{~mm}$ long. Achenes are small, 0.4$0.8 \mathrm{~mm}$ long, $0.15-0.25 \mathrm{~mm}$ wide, ecoronate, brown and copiously mucilaginous. Their anterior surface is smooth and posterior surface has 3-4 whitish ribs.

$\mathrm{Phenology:}$ Flowering and fruiting from March to May.

$\mathrm{Hab}$ it a t: Growing along roadsides and cultivated ground/arable land, sand, flood-plain meadows with stony soil.
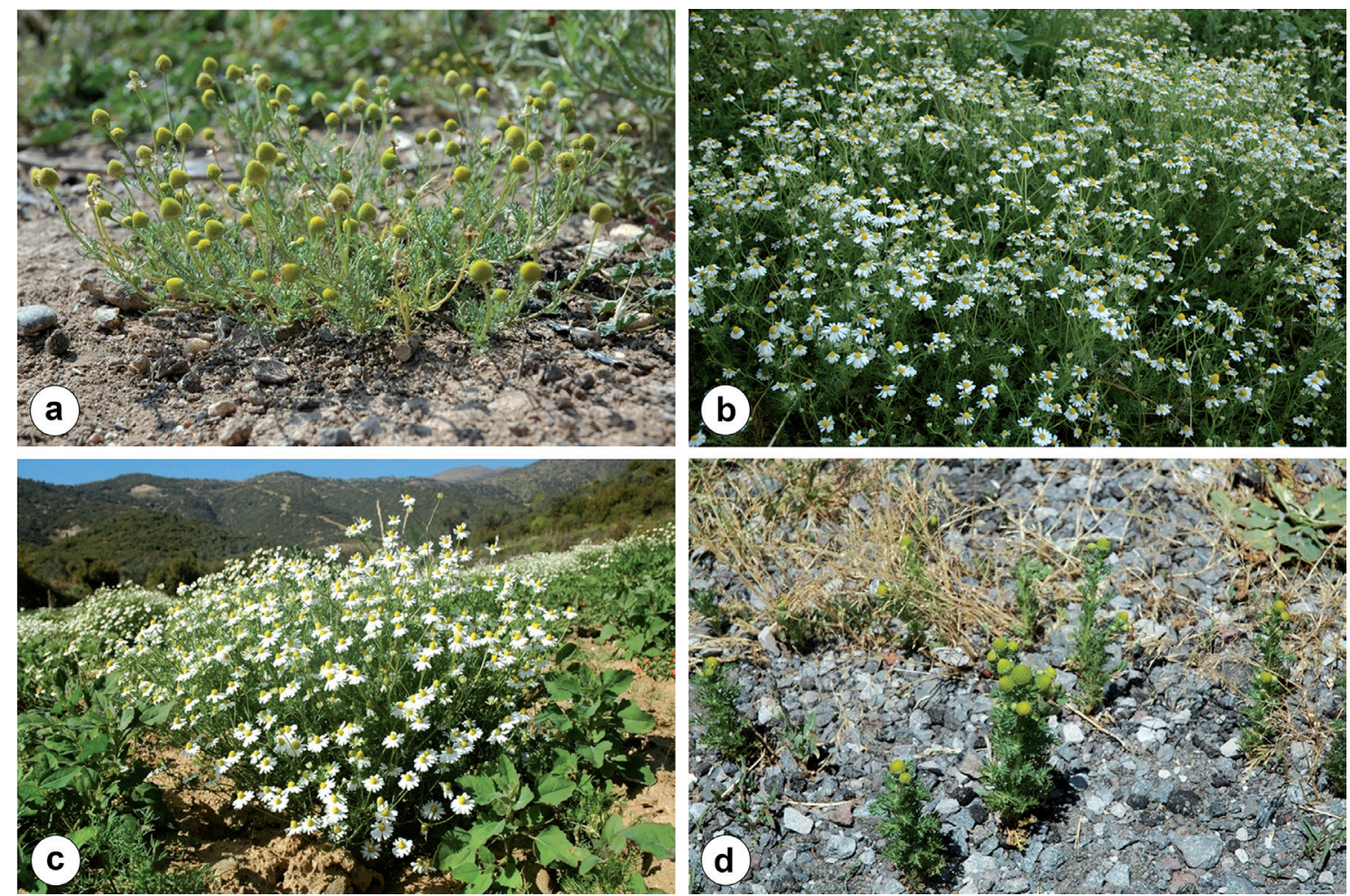

Fig. 1. General habit of Matricaria taxa

Explanations: $\mathrm{a}-$ M. aurea $\mathrm{b}-$ M. chamomilla var. chamomilla, $\mathrm{c}-$ M. chamomilla var. recutita, $\mathrm{d}-$ M. matricarioides. Photographs: $\mathrm{a}-\mathrm{Murat}$ Bal with permission; b, c \& d - Huseyin Inceer 
Distribution: This species is distributed in south and southeast Anatolia, rare.

Notes: This species is similar to M. matricarioides, but differs in having mucilaginous and ecoronate achenes. It is especially adapted to dry habitats. The presence of mucilage in the achenes is an important adaptive feature for this species.

Chromosome number: $2 \mathrm{n}=2 \mathrm{x}=18$ (Inceer \& Hayırlığlu-Ayaz 2010).

Specimens examined: Turkey. C3 Antalya: Myra, 5 m, 18 April 2007, Inceer 310b (KTUB); C6 Gaziantep/Şanlıurfa: Between Nizip and Birecik, $440 \mathrm{~m}$, 8 May 2007, Inceer 322 (KTUB); C6 Gaziantep: Nizip, 448 m, 9 May 2009, Inceer 720 (KTUB).

\section{Matricaria chamomilla L., Sp. P1. 891 (1753).}

Morphology: The plant is annual. Stems are 10$50 \mathrm{~cm}$ tall, glabrous or sparsely pubescent. Leaves are 2-3-pinnatisect, and ultimate segments of them are narrow. Lower leaves are 5-7 cm long and glabrous, but they are sometimes pubescent. The primer segments of the leaves are 9-12-paired. Capitula are usually solitary, and, sometimes, corymbose or subcorymbose with short or long peduncles. Receptacle is oblong-conical. Involucral bracts are usually 1-seriate, green and obtuse with whitish-membranous margins. Ray flowers are female with 11-20 per capitulum, ligules are white and 3-8.5 mm long, which are patent at first, and then recurved. Disc flowers are 10-20 mm long, numerous, hermaphrodite and yellow with 5 lobes. Achenes are vey small, 0.7-1.05 mm long, 0.25-0.4 $\mathrm{mm}$ wide, coronate or ecoronate, brown and mucilaginous. Their anterior surfece is smooth and posterior surface has 4-5 whitish ribs.

Key to the varieties of $M$. chamomilla

1. Peripheral achenes only with coronas

2a.var. chamomilla

$1^{*}$ Achenes all naked, ecoronate ......... 2b.var. recutita

2a. Matricaria chamomilla L. var. chamomilla (Fig. 1b). Phenology: Flowering and fruiting from March to June.

$\mathrm{Hab}$ it at: Growing along roadsides, waste and cultivated grounds/arable land.

Distribution: It is distributed in west, south Anatolia and the European part of Turkey. This taxon is widespread as a cosmopolitan weed in other territories as well as Turkey.

Chromosome number: $2 \mathrm{n}=2 \mathrm{x}=18$ (Inceer \& Ozcan 2011).

Notes: var. chamomilla is distinguished by having coronas on peripheral achenes. The central achenes are ecoronate. The presence of mucilage in the achenes is an important adaptive feature for this taxon.
Specimens examined: Turkey. A1 Çanakkale: Koru Dağ 1,70 m, 11 May 2007, Inceer 331-332 (KTUB); A2 Tekirdağ: Silivri, 45 m, 16 April 2008, Inceer 505 (KTUB); C1 Muğla: Fethiye, 50 m, 17 April 2007, Inceer 295 (KTUB); C1 Muğla: Marmaris, between Marmaris and Köyceğiz, 20 m, 18 April 2007, Inceer 305 (KTUB); C2 Denizli: Pamukkale, 160 m, 11 April 2008, Inceer 500 (KTUB); C2 Aydın: İncirlikova, 65 m, 11 April 2008, Inceer 503 (KTUB); C3 Antalya; Finike, 26 m, 18 April 2007, Inceer 309 (KTUB); C3 Antalya: Elmal1, 220 m, 19 April 2007, Inceer 312 (KTUB).

2b. Matricaria chamomilla L. var. recutita (L.) Fiori, Nouv.Fl. Ital. 2: 620 (1927), (Fig. 1c).

$\mathrm{Phenology:}$ Flowering and fruiting from March to June.

$\mathrm{H}$ a b i t a t: Growing along roadsides, waste and cultivated grounds/arable land.

Distribution: It is widespread in Turkey. This taxon is widespread as a cosmopolitan weed in other territories as well as Turkey.

Chromosome number: $2 \mathrm{n}=2 \mathrm{x}=18$ (Inceer \& Hayırlığlu-Ayaz 2010).

N o t e s: var. recutita is very similar to the typical variety, but is distinguished by having ecoronate achenes. The presence of mucilage in the achenes is an important adaptive feature for this taxon.

Specimen examined: Turkey. A1 Tekirdağ: Köse İlyas Village, 130 m, 10 May 2007, Inceer 324 (KTUB); A1 Edirne: Keşan, 100 m, 11 May 2007, Inceer 326 (KTUB); A1 Balıkesir: Bandırma, 150 m, 12 May 2007, Inceer 341 (KTUB); A2 Bursa: Uludağ, 1700 m, 28 June 2007, Inceer 365 (KTUB); A7 Trabzon: Değirmendere, 10 m, 14 May 2007, Inceer 345 (KTUB); B1 İzmir: Yamanlar Dağı, 750 m, 15 April 2007, Inceer 278 (KTUB); B1 Çanakkale: Bayramiç, 250 m, 12 May 2007, Inceer 334 (KTUB); B3 Eskişehir: Mihalgazi, 282 m, 8 June 2008, Inceer 544 (KTUB), C1 Muğla: Bodrum, Ortakent, 132 m, 16 April 2007, Inceer 283a (KTUB); C2 Muğla: Köyceğiz, 12 m, 18 April 2007, Inceer 303 (KTUB).

3. Matricaria matricarioides (Less.) Porter, Mem. Torrey Bot. Club 5: 341 (1894), (Fig. 1d).

Morphology: The plant is annual, strongly aromatic and pineapple-scented. Roots are thick with numerous slender branches. Stems are several, $2-45 \mathrm{~cm}$ tall, erect or ascending, mostly branched in upper half, glabrous, sometimes minutely pubescent below capitula. Leaves 2-3-pinnatisect. The inflorescence is corymbose. Capitula are 5 to numerous, $5-15 \mathrm{~mm}$ width with short peduncles. Receptacles are ovoid-conical. Involucral bracts are 3-seriate, elliptical or obtuse with colourless with scarious margins. All florets are tubular, numerous, 
yellow with 4 lobes. Achenes are oblong, brownish, 0.8-1.5 mm long, 0.4-0.6 mm wide non-mucilaginous. their anterior surface is smooth, posteriorly 4-ribbed, lateral ribs reddish, especially above. Pappus is a short rim, with entire margin.

Phenology: Flowering and fruiting from June to August.

H a bit at: Roadsides, fields and meadows.

D i s tribution: It is distributed in east and northeast Anatolia. This species is widespread as a cosmopolitan weed in other territories.

Chromosome number: $2 \mathrm{n}=2 \mathrm{x}=18$ (Inceer \& Hayırlığlu-Ayaz 2010).

Notes: The distinguishing features of this species are non-mucilaginous achenes, greenish disc flowers and pineapple scent.

Specimens examined: Turkey. A9 Kars: From Ardahan to Göle, 1800 m, 18 July 2007, Inceer 420 (KTUB); A9 Artvin: Şavşat, 964 m, 20 June 2009, Inceer 744b (KTUB); B8 Erzurum: Erzurum, 1800 m, 13 July 2008, Inceer 655 (KTUB).
Matricaria chamomilla var. coronata J. Gay ex Boiss., Voy. Bot. Espagne 2: 316 (1840), erroneously reported. N o t e s: This taxon has been poorly known/recognised in Turkey, and it has not been collected from Turkey since its introduction to the Flora of Turkey and the East Aegean Islands by Grierson $(1974,1975)$. In the taxonomic treatment of Matricaria in the Flora of Turkey, M. chamomilla var. coronata was considered synonym of M. chamomilla var. pappulosa, and it was cited with only one collection (Huber-Morath 16838) from Muğla Province (Grierson 1975). According to the most recent taxonomic treatment of $M$. chamomilla (Applequist 2002), M. chamomilla var. pappulosa is synonym of M. chamomilla var. coronata.

During extensive field studies for the project "Revision of the Genera Matricaria and Tripleurospermum in Turkey", many Matricaria specimens were collected from Muğla Province as well as other provinces of Turkey. However, none of them was represented by $M$. chamomilla var. coronata, and it was noted doubtfully record for the flora of Turkey (Inceer 2012).
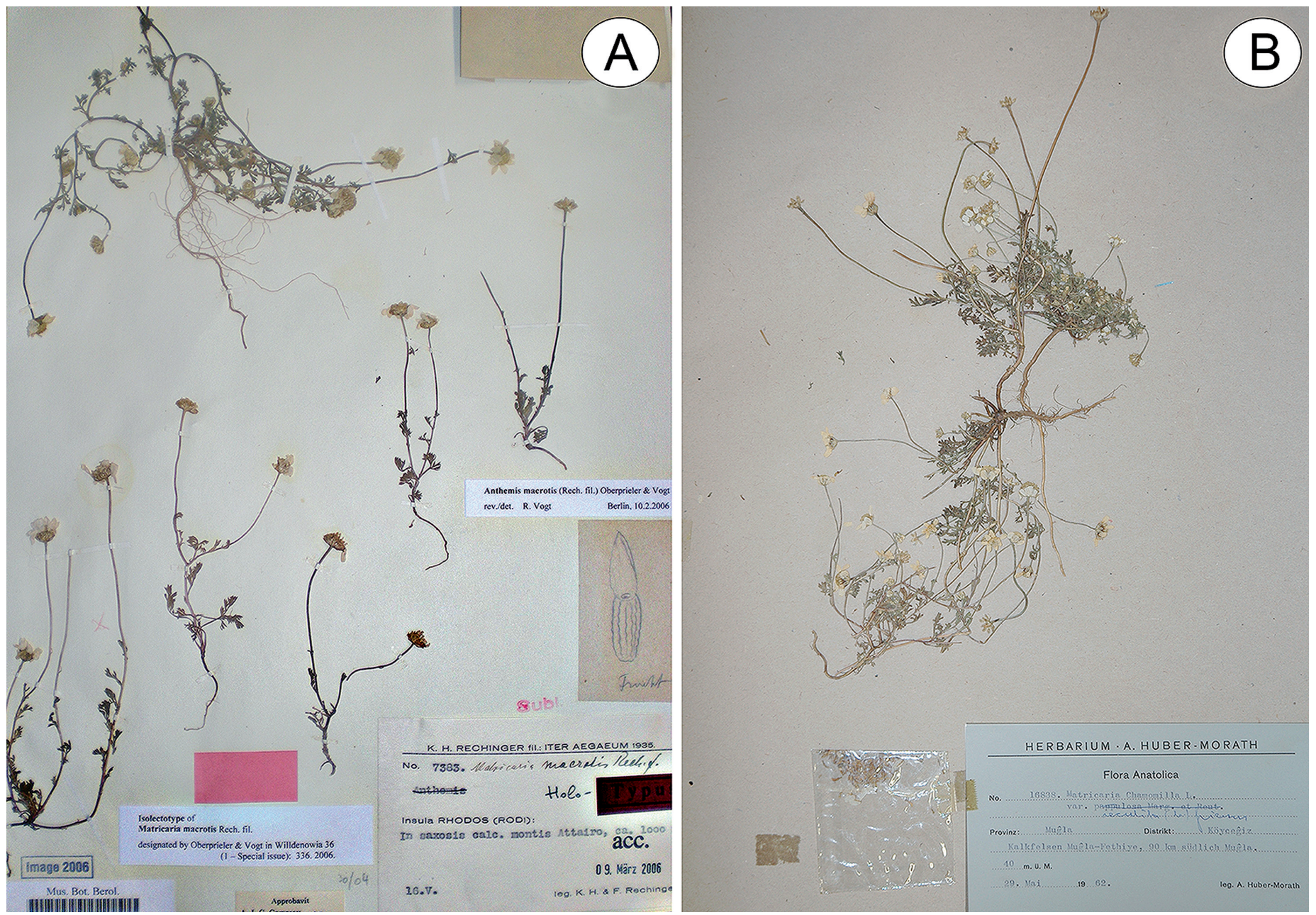

Fig. 2. Images of herbarium sheets of Anthemis macrotis

Explanations: A - Rechinger 7383 in the Berlin herbarium (B), B - Huber-Morath 16838 in the Geneva herbarium (G). Photographs: Huseyin Inceer 
Table 1. Distribution and life form of Matricaria taxa studied in Turkey

\begin{tabular}{|c|c|c|c|c|c|c|c|c|c|c|}
\hline Taxon & Chorotype & $\begin{array}{l}\text { Life } \\
\text { form }\end{array}$ & NW & $\mathrm{N}$ & $\mathrm{NE}$ & W & E & $\mathrm{S}$ & $\mathrm{SE}$ & $\mathrm{C}$ \\
\hline Matricaria aurea & EM/ARI & $\mathrm{Th}$ & & & & & & + & + & \\
\hline $\begin{array}{l}\text { Matricaria chamomilla } \\
\text { var. chamomilla }\end{array}$ & EM & Th & + & & & + & & + & & \\
\hline $\begin{array}{l}\text { Matricaria chamomilla } \\
\text { var. recutita }\end{array}$ & $\mathrm{EM} / \mathrm{CA} / \mathrm{E}$ & Th & + & + & & + & & + & & + \\
\hline Matricaria matricarioides & ARI & $\mathrm{Th}$ & & & + & & + & & & \\
\hline
\end{tabular}

Explanations: + - present, Th - therophyte, ARI - Armeno-Iranian Province, EM - East Mediterranean Province, EM/CA/E - East Mediterranean Province/ Central Anatolian Province/Euxine

The specimens of M. chamomilla var. coronata cited in the Flora of Turkey were traced at herbarium G. After a close examination of the specimens deposited at $\mathrm{G}$ and cross-checking with descriptions in the Flora of Turkey, it was realized that the specimens were morphologically different from $M$. chamomilla var. coronata. These specimens (Fig. 2) belong to Anthemis macrotis (三 Matricaria macrotis). This finding revealed that there was a misidentification for Huber-Morath's collection cited in the Flora of Turkey. As a result, the gathering record cited in the Flora of Turkey of M. chamomilla var. coronata belong to A. macrotis. It was concluded that $M$. chamomilla var. coronata was erroneously reported for the flora of Turkey. Additionally, inspection of Matricaria collections at the ANK, B, E, EGE, EDTU, GAZI and HUB herbaria as well as field surveys to date have not confirmed the occurrence of this taxon in Turkey.

Specimens examined: Turkey. C2 Muğla: $90 \mathrm{~km}$ from Muğla to Fethiye, $40 \mathrm{~m}$, Köyceğiz, HubMor 16838 (G!). Anthemis macrotis: Greece. Rodhos, M. Attairo, Kastterrain, ca. 1000 m, Rechinger 7383 (holotype B!).

\section{Phytogeographical patterns and life form}

Phytogeographical elements of the Matricaria taxa in Turkey are Mediterranean, Armeno-Iranian, Central Anatolian and Euxine (Table 1). As seen from Table 1, fifty percent of the taxa of Matricaria are mono-regional elements. The rest are bi- or tri-regional in distribution. On the other hand, Mediterranean elements are predominant. These findings confirm the previous data about the chrology of the taxa of Matricaria in the Turkish flora (Yildirimli 1999).

Oberprieler (2005) reported that the Mediterranean region played a paramount role in the diversity of the Asteraceae tribe Anthemideae. In addition, the likely ancestral distribution of Matricaria was Asia Minor, Caucasus and east Europe (Oberprieler 2005). The taxonomic diversity of this genus is highest in Asia Minor, the Caucasus and the Near East. The present findings showed that the Mediterranean region of Turkey is rich in Matricaria taxa.

Matricaria chamomilla var. chamomilla and M. chamomilla var. recutita are widely distributed in Turkey (Table 1), while M. aurea and M. matricarioides have limited distribution. The present results are in agreement with previous data (Grierson 1975; Davis et al. 1988; Yildirimli 1999; Inceer 2012).

The present results show that the life form of the Matricaria taxa is therophyte (Table 1). According to Raunkiaer (1934), the biological spectra of Mediterranean-type regions are characterized by high percentages of therophytes. The short life cycle in therophytes may play an important role in the adaptation at low altitudes as well as mild climates of the Mediterranean.

Acknowledgements. The author thanks Dr. Melahat Ozcan, Dr. Faik Ahmet Ayaz and Murat Bal for help during the development of this study; the curators of the ANK, B, E, EGE, EDTU, G, GAZI and HUB herbaria for help in the herbarium studies, and the Scientific and Technological Research Council of Turkey (TUBITAK, Project No. 106T162) for financial support. SYNTHESYS provided the funding for the visit to the Royal Botanic Garden, Edinburgh (GB-TAF-1175) for the corresponding author. 


\section{References}

Applequist W. L. 2002. A reassesment of the nomenclature of Matricaria L. and Tripleurospermum Sch. Bip. (Asteraceae). Taxon 51: 757-761.

Bremer K. \& Humphries C. J. 1993. Generic monograph of the Asteraceae-Anthemideae. Bulletin Natural History Museum London (Botany) 23: 71-177.

Bremer K., Eklund H., Medhanie G., Heidmarsson S., LauRent N., MaAd J., Niklasson J. \& Nordin A. 1996. On the delimitation of Matricaria versus Microcephala (Asteraceae: Anthemideae). Plant Syst Evol 200: 263-271.

Davis P. H., TAN K. \& Mill R. R. 1988. Flora of Turkey and the East Aegean Islands, vol. 10, pp. 163. Edinburgh University Press, Edinburgh.

Greuter W. \& von RaAb-Straube E. 2008. Med-Checklist: A Critical Inventory of Vascular Plants of CircumMediterranean Countries, vol. 2. OPTIMA, Geneve, Switzerland.

Grierson A. J. C. 1974. Matricaria. In: P. H. Davis (ed.). Materials for a flora of Turkey XXX. Notes Roy. Bot. Gard. Edinburgh 33: 252-254.

Grierson A. J. C. 1975. Matricaria L. In: P. H. Davis (ed.). Flora of Turkey and the East Aegean Islands, vol. 5, pp. 293-295. Edinburgh University Press, Edinburgh.

INCEER H. 2011. Achene slime content in some taxa of Matricaria L. (Asteraceae). Acta Bot Croat 70: 109-114.

InCEer H. 2012. Matricaria. In: A. Guner, S. Aslan, T. EkIM, M. Vural \& M. T. BABAÇ (eds.). Türkiye Bitkileri Listesi (Damarlı Bitkiler), pp. 183-184. Nezaket Gökyiğit Botanik Bahçesi ve Flora Araştırmaları Derneği Yayını, İstanbul (in Turkish).

InCEER H. \& HaYirlioglu-Ayaz S. 2010. Chromosome numbers in Tripleurospermum Sch. Bip. (Asteraceae) and closely related genera: relationships between ploidy level and stomatal length. Plant Syst Evol 285:149157.

InCEER H. \& OzCAN M. 2011. Leaf anatomy as an additional taxonomy tool for 18 taxa of Matricaria L. and Tripleurospermum Sch. Bip. (Anthemideae-Asteraceae). Plant Syst Evol 296: 205-215.

KaY Q. O. N. 1976. Matricaria L. \& Chamomilla S. F. Gray. In: T. G. Tutin, V. H. Heywood, N. A. Burges, D. M. Moore, D. H. Valentine, S. M. Walters, D. A. WebB (eds.). Flora Europaea, vol. 4, pp. 165-167. Cambridge University Press, Cambridge.

Oberprieler C. 2005. Temporal and spatial diversification of Circum-Mediterranean Compositae-Anthemideae. Taxon 54: 951-966.

Oberprieler C. \& Vogt R. 2006. The taxonomic position of Matricaria macrotis (Compositae-Anthemideae). Willdenowia 36: 329-338.

Oberprieler C.,Vogt R. \& Watson L. E. 2007. XVI. Tribe Anthemideae Cass. In: J. W. Kadereit \& C. JefFrey (eds.). Flowering plants eudicots, K. KuBITZKi (ed.). The families and genera of vascular plants, vol. 8, pp. 342-374. Springer-Verlag, Berlin Heidenberg.

RaunKiaer C. 1934. Life forms of plants and statistical plant geography. Calderon Press, Oxford.

RAuschert S. 1974. Nomenklatorische probleme in der Gattung Matricaria L. Folia Geobot Phytotax 9: 249-260.

TAKhtajan A. 1986. Floristic regions of the world. 522 pp. University California Press, California.

YILDIRIMLI S. 1999. The chorology of the Turkish species of Asteraceae. Ot Sit Bot Dergisi 6(2): 75-123. 